\title{
第56回日本臨床ウイルス学会開催報告
}

\section{The 56th Annual Meeting of the Japanese Society for Clinical Virology}

\section{会長 山田雅夫 (岡山大学大学院医歯薬学総合研究科 病原ウイルス学)}

Masao Yamada (Department of Virology, Okayama University Graduate School of Medicine, Dentistry and Pharmaceutical Sciences)

\section{去る平成27年 6 月 13 日（土） 14日（日）第56回日} 本臨床ウイルス学会を岡山大学鹿田キャンパス Junko Fukutake Hall（Jホール）他にて開催し, 会長を務め ました。本学会は, 全国の小児科, 内科, 皮虐科, 眼 科など, 多岐に渡る臨床医学分野・診療科の医師・研 究者から, 国立感染症研究所, 全国地方衛生研究所で のウイルス検査担当者を含めた基礎研究者, 企業等で ウイルス・ワクチンに関する研究・開発に携わる専門 家まで, 多様な分野の先生方で構成されています。両 日とも好天にも恵まれて, 約 350 名の参加者を迎え, 盛 況のうち, 58の一般演題について活発な討議が行われ ました。

今回の学会テーマは「その時その場の使命」としま した. 医学ウイルス学が, 今後も若き優秀な医学研究 者 (Physician Scientist) を引き寄せる研究領域である ように, 医学ウイルス学の解決すべき重要な課題に, 臨床ウイルス学会とウイルス学会が一致協力して取り 組むことができるようにするには，どうあるべきなの かを一緒に考えていきたく思い,このテーマとしました。

このテーマに沿って, 学会 1 日目午後には, シンポ ジウム 1 「感染研・地衛研の連携：その時その場の使 命」を開催し, エボラ出血熱, デング熱, SFTS, 原
因不明の脳炎・脳症などの喫緊の課題に，国立感染症 研究所と地方衛生研究所がどのように連携して取り組 むのか討論を深めていただきました，司会は，国立感 染症研究所 西條政幸部長と愛知県衛生研究所 皆川洋 子所長にお願いし，特に西條部長には，隣国で流行し ていた MERS コロナウイルスについての解説を急き よお願いしました。

また学会 2 日目には, パネルデイスカッション「医 学ウイルス学 : その時その場の使命」を開催し, ウイ ルス学会, 臨床ウイルス学会の歴代会長に, 国際連携 による感染症研究 (生田和良先生), 重症ウイルス感染 症: 病態解析から治療法の確立へ(森島恒雄先生), 抗 インフルエンザ薬の創薬（Favipiravir）（白木公康先 生), 臨床ウイルス学・臨床免疫学からみたワクチン研 究（庵原俊昭先生）について研究成果を紹介していた だき，併せて次世代の研究者に対して貴重な提言もい ただきました。

さらに, 学会 1 日目午前に若手奨励賞候補演題セッ ションを開きました. 26 題の対象応募演題から選定し た 9 題について, 参加会員が一同に会して発表を聞き, 3 名の若手奨励賞受賞者を選考しました。昨年度から 始まった若手奨励賞ですが, 多くの応募があり, 確実

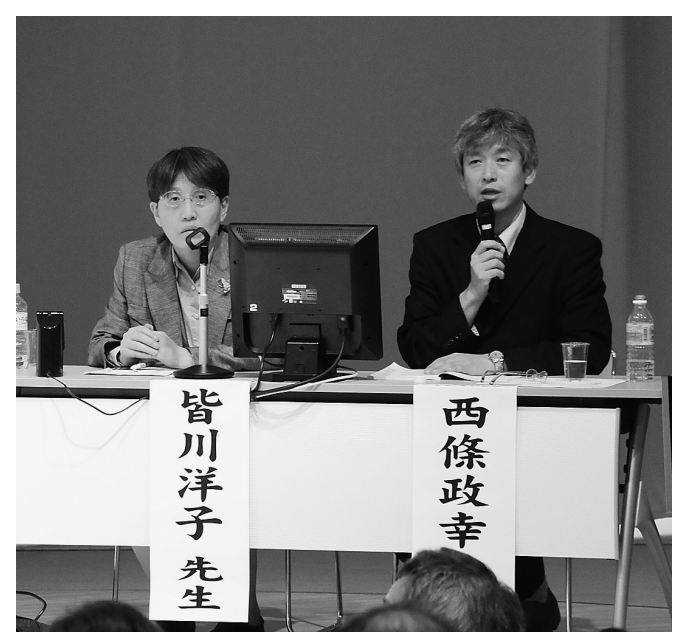

シンポジウム 1

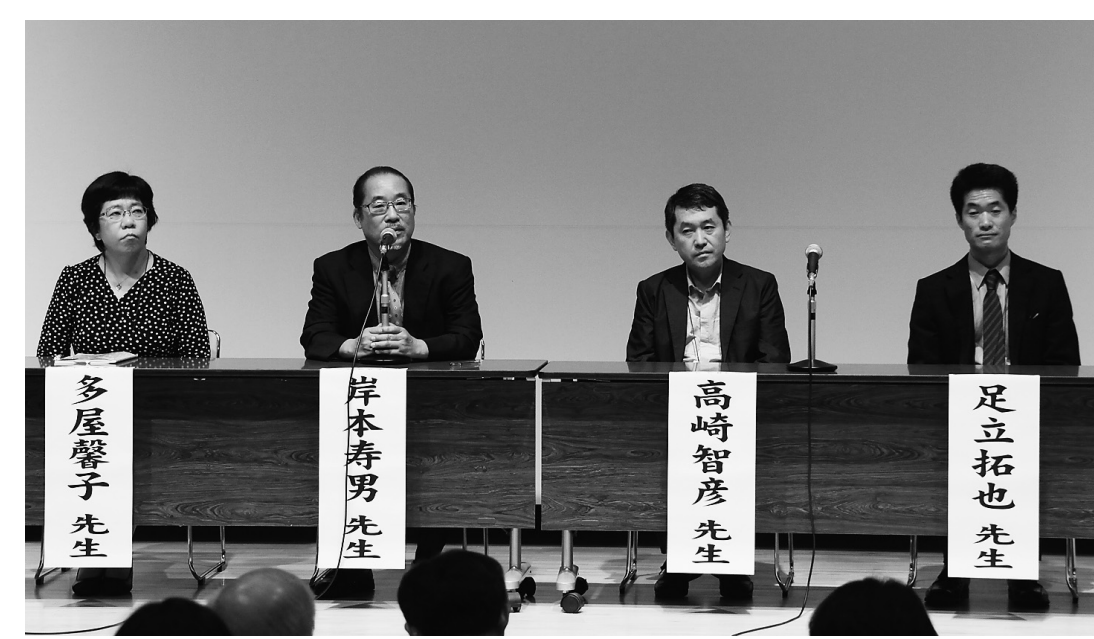

：その時その場の使命」 
に若手研究者層の拡大と充実ぶりを実感しました。

今年 3 月我が国からの麻疹排除をWHO が認定し たことを記念して, 特別企画：「祝 WHO 麻疹排除

(measles elimination) 認定」を学会 2 日目午後一番 に設け, 川崎市健康安全研究所 岡部信彦所長に経緯を 振り返ってご講演をお願いし会員一同でお祝いたしま した。

新しい切り口のシンポジウムとして「日常診療に直 結するサーベイランス体制を!」を, 独立行政法人国 立病院機構三重病院 谷口清州先生, 川崎医科大学小児 科学 中野貴司教授に企画いただき, 好評を博しまし

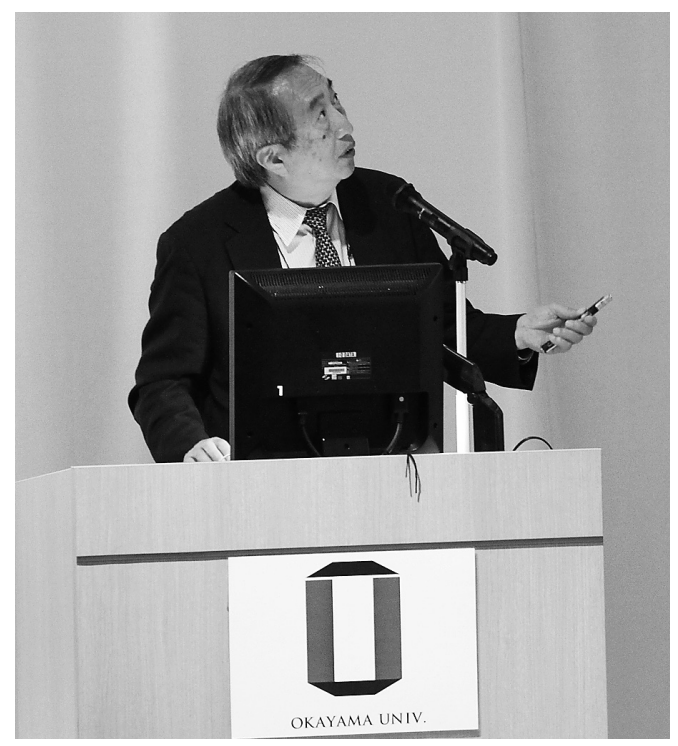

特別企画「祝 WHO 麻疹排除認定」岡部信彦先生
た.また，特別講演では，同門の公文裕巳名誉教授に， 「固形がんに対する魔法の弾丸 “Ad-REIC 遺伝子治療 薬”」を扔話しいただき，私は「へルペスウイルスの病 態と自然史」について会長講演をいたしました。

最後になりましたが, この場をお借りして，学会の 開催をご支援いただきました企業の各位，同門の方々 に厚くお礼申し上げます。また学会の企画段階からご 指導・ご支援いただきました小児科学分野の森島名誉 教授，塚原教授に心から感謝申し上げます。

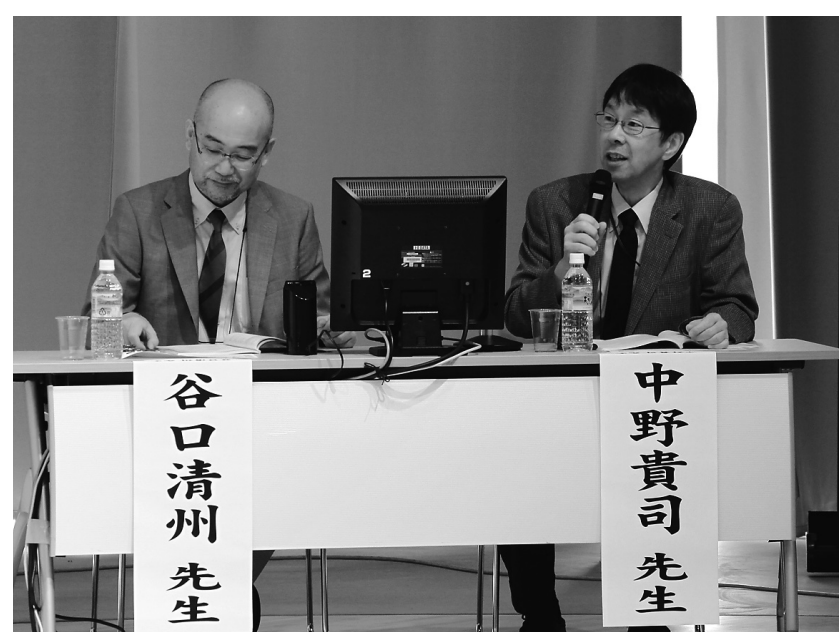

シンポジウム $2\lceil$ 日常診療に直結するサーベイランス体制を!」

平成 27 年 9 月受理

于700-8558 岡山市北区鹿田町 2-5-1

電話：086-235-7163 FAX：086-235-7169

E-mail :masao@okayama-u.ac.jp 